Research article

\title{
How clear-cutting affects fire severity and soil properties in a Mediterranean ecosystem
}

\author{
Marcos Francos a, *, Paulo Pereira ${ }^{b}$, Jorge Mataix-Solera ${ }^{c}$, Victoria Arcenegui ${ }^{\text {, }}$ \\ Meritxell Alcañiz ${ }^{a}$, Xavier Úbeda ${ }^{a}$ \\ ${ }^{a}$ GRAM (Grup de Recerca Ambiental Mediterrània), Department of Geography, University of Barcelona, Montalegre, 6, 08001, Barcelona, Spain \\ ${ }^{\mathrm{b}}$ Environmental Management Centre, Mykolas Romeris University, Vilnius, Lithuania

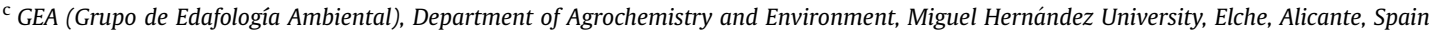

\section{A R T I C L E I N F O}

\section{Article history:}

Received 3 August 2017

Received in revised form

2 November 2017

Accepted 4 November 2017

\section{Keywords:}

Pre-fire management

Soil properties

Fire severity

Wildfire

\begin{abstract}
A B S T R A C T
Forest management practices in Mediterranean ecosystems are frequently employed to reduce both the risk and severity of wildfires. However, these pre-fire treatments may influence the effects of wildfire events on soil properties. The aim of this study is to examine the short-term effects of a wildfire that broke out in 2015 on the soil properties of three sites: two exposed to management practices in different years - 2005 (site M05B) and 2015 (site M15B) - and one that did not undergo any management (NMB) and to compare their properties with those recorded in a plot (Control) unaffected by the 2015 wildfire. We analyzed aggregate stability (AS), soil organic matter (SOM) content, total nitrogen (TN), carbon/ nitrogen ratio $(\mathrm{C} / \mathrm{N})$, inorganic carbon (IC), $\mathrm{pH}$, electrical conductivity $(\mathrm{EC})$, extractable calcium $(\mathrm{Ca})$, magnesium $(\mathrm{Mg})$, sodium $(\mathrm{Na})$, and potassium $(\mathrm{K})$, microbial biomass carbon $\left(\mathrm{C}_{\mathrm{mic}}\right)$ and basal soil respiration (BSR). In the managed plots, a clear-cutting operation was conducted, whereby part of the vegetation was cut and left covering the soil surface. The AS values recorded at the Control site were significantly higher than those recorded at M05B, whereas the TN and SOM values at NMB were significantly higher than those recorded at M05B. IC was significantly higher at M05B than at the other plots. There were no significant differences in $\mathrm{C} / \mathrm{N}$ ratio between the analyzed sites. Soil pH at M05B was significantly higher than the value recorded at the Control plot. Extractable Ca was significantly higher at NMB than at both M05B and the Control, while extractable Mg was significantly lower at M05B than at NMB. Extractable $K$ was significantly lower at the Control than at the three fire-affected plots. $C_{m i c}$ was significantly higher at NMB than at the Control. BSR, BSR/C and BSR $/ C_{m i c}$ values at the fire-affected sites were significantly lower than those recorded at the Control. No significant differences were identified in $\mathrm{C}_{\text {mic }} / \mathrm{C}$. Overall, a comparison of the pre-fire treatments showed that NMB was the practice that had the least negative effects on the soil properties studied, followed by M15B, and that fire severity was highest at M05B due to the accumulation of dead plant fuel.
\end{abstract}

๑) 2017 Elsevier Ltd. All rights reserved.

\section{Introduction}

Mediterranean ecosystems are characterized by the frequent occurrence and recurrence of fire (Tessler et al., 2016a, 2016b), which has, however, made these environments highly resilient to such events (Francos et al., 2016a; Keeley et al., 2012). Indeed, Mediterranean wildfires have been identified as one of the main disturbances suffered by these ecosystems (Bond and Van Wilgen, 1996), exacerbated by centuries of human impact and the use of fire

\footnotetext{
* Corresponding author.

E-mail address: marcosfrancos91@gmail.com (M. Francos).
}

for land management. More recently, land abandonment, fire suppression policies and climate change have increased the vulnerability of Mediterranean forests to wildfires (Pereira et al., 2016). In response, clear-cutting and prescribed fires are practices that seek to reduce the amount of fuel and, hence, the fire risk (Alcañiz et al., 2016; Cochrane et al., 2012; Corona et al., 2015). These forest management practices also reduce fire severity in Mediterranean environments (Corona et al., 2015; Keeley, 2009; Simard, 1991), an effect that can be maintained for up to 10 years. Yet, despite the medium- and long-term advantages of these practices, restrictions in the budget assigned to forestry management limit their implementation and, therefore, the capacity to mitigate the impact of wildfires (Martín-Alcón and Coll, 2016). 
Recently, fire has been identified as a soil forming factor (Certini, 2014), and it has been widely reported as a temporary modifier of soil properties. The degree of this impact depends on pre-fire conditions, the type of soils affected and the severity of the fire. For example, low-to-moderate severity fires do not have a significant direct impact (e.g. heating) on a soil's physical and chemical properties (Francos et al., 2018). The changes recorded are attributable primarily to the ash produced by the fire in conjunction with the post-environmental conditions, including local topography and rainfall (Arcenegui et al., 2008; Certini, 2005; Francos et al., 2016a; Gordillo-Rivero et al., 2014; Pereira et al., 2014a, 2017). Thus, for example, low-to-moderate severity fires have been reported to increase soil aggregate stability (AS) (Mataix-Solera et al., 2011); soil organic matter (SOM) (Inbar et al., 2014; Pereira et al., 2014b; Úbeda et al., 2005); total carbon (TC) and total nitrogen (TN) (De Marcos et al., 2005; González-Pérez et al., 2004); pH; electrical conductivity (EC) and the major extractable elements (Alcañiz et al., 2016; Liu et al., 2017), as a consequence of ash incorporation into the soil profile (Bodí et al., 2014). However, fires can also have various direct impacts on soil microbiology. Indeed, even low temperature fires can reduce soil microbial biomass and respiration (Certini, 2005), given the increase in temperature at the soil surface. The duration of the fire episode is one characteristic that can have the greatest impact on soil biology: the longer the duration of the wildfire, the greater the impact on underground soils (Mataix Solera et al., 2009). However, low-to-moderate severity fires normally move rapidly and most of their heat is released in an upwards direction, which means their impact on soils is not great. Having said that, though, the heat generated in such fires might be enough to modify soil microbiology activity, since the threshold is low at between 40 and $121^{\circ} \mathrm{C}$ (Mataix Solera et al., 2009), a temperature that is readily reached in the top few centimeters of the soil profile (Augustine et al., 2014; Kennard and Gholz, 2001). After the fire line is passed, the ash deposited on the soil surface, in conjunction with the post-fire environmental conditions, dictate the soil microbiology. Low-to-moderate fire severities produce reddish, black ashes (Pereira et al., 2012, 2014a), which can raise soil temperatures due to increased albedo, and provoke microbiological activity that contributes to a more rapid landscape recovery (Andersson et al., 2004; Bodí et al., 2014; Mataix Solera et al., 2009).

High severity wildfires, in contrast, can consume the entire litter layer and the SOM. This greatly undermines soil protection (Pereira et al., 2015a) and leads to major changes in the top layer of the soil. Such fires have been reported as both reducing (Badia-Villas et al., 2014) and increasing (Jiménez-Pinilla et al., 2016) soil AS, depending on the temperature of combustion. Indeed, AS may fall as a result of organic matter consumption or increase due to mineralogical changes induced by high temperatures. Several studies have reported a fall in SOM (Holden et al., 2015), TC and TN (Badia et al., 2014; Ulery et al., 2017), because of high temperatures. As in low to moderate severity fires, $\mathrm{pH}$ and EC normally increase as a result of high organic matter mineralization, which increases the availability of the major cations (Lombao et al., 2015; Úbeda and Outeiro, 2009). The ash layer is grey and/or white in color, as a consequence of the total combustion of organic matter, which increases the amount of inorganic cations in soil solution (Pereira et al., 2012). High severity wildfires reduce microbial activity significantly in the immediate post-fire period due to the high temperatures recorded in the soil surface; however, normal activity is usually recovered a few months after the fire as a result of an increase in soil moisture, nutrients and vegetation recuperation (Fultz et al., 2016; Muñoz-Rojas et al., 2016).

While a considerable amount of information has been gathered about the impact of pre-fire treatment on fire severity and the short-, medium- and long-term implications of such events, little research has been conducted into their respective effects on soil properties, especially in the immediate post-fire period, when the impact is most evident, and it is possible to evaluate the impact of pre-fire management and its effectiveness in reducing the impact of fire on soils. Moreover, the degree to which fire affects soil and soil conditions in the period immediately following a fire is crucial for plant recuperation (Pereira et al., 2016). This study of pre-fire management impact on soil properties is essential to understand the effectiveness of land management in sites, such as those in areas of Catalonia, that are prone to fire.

The objectives of this study are easily stated:

a) To examine the impact of clear cutting on soil AS, TN, SOM, inorganic carbon (IC), C/N ratio, $\mathrm{pH}, \mathrm{EC}$, extractable calcium (Ca), magnesium $(\mathrm{Mg})$, sodium $(\mathrm{Na})$, potassium $(\mathrm{K})$, microbial biomass carbon (Cmic), basal soil respiration (BSR), and the $\mathrm{Cmic} / \mathrm{C}, \mathrm{BSR} / \mathrm{C}$ and $\mathrm{BSR} / \mathrm{Cmic}$ ratios

b) To examine the influence of the time lapse between the management of the site and the wildfire and to determine if the treatment results in differences in the soil's post-fire properties.

\section{Materials and methods}

\subsection{Study site}

The study site is located in Ódena, Barcelona $\left(41^{\circ} 38^{\prime} 42^{\prime \prime} \mathrm{N}\right.$ $1^{\circ} 44^{\prime} 21 \mathrm{E} 420 \mathrm{~m}$ a.s.l.) in North-East Spain (Fig. 1). A fire broke out in El Bruc, on 26th July 2015 and affected a total of 1274 ha of Pinus halepensis Miller, Pinus nigra Arnold and Quercus ilex L. Understory vegetation was mainly composed of Pistacea lentiscus L. and Genista scopius L. The forest had last been affected by wildfire in 1986 . The geological substrate is composed mainly of sediments originated from Paleocene shale (Panareda-Clopés and Nuet-Badia, 1993). Soil is classified as a Fluventic Haploxerept (Soil Survey Staff, 2014). The mean annual temperature of the study site is $14.2{ }^{\circ} \mathrm{C}$ and the mean annual rainfall ranges between 500 and $600 \mathrm{~mm}$.

\subsection{Experimental design and sampling}

In this study, four different sites were selected within the site and sampled three months after the 2015 wildfire: one was not exposed to any management (NMB), one underwent management in 2005 (M05B), another was the target of a management program in 2015 - just two months before the wildfire event (M15B), and as a reference, a control plot was selected (Control), which had not been exposed to any management after the fire of 1986 and was unaffected by the wildfire in 2015 (Table 1). The management treatment involved a clear-cutting operation, leaving 1000 trees per ha and leaving the cut vegetation over the soil surface in stems no taller than $1 \mathrm{~m}$. In the case of the trees that were not felled, up to a third of their branches were removed. The wood was cut to a height of $1 \mathrm{~m}$, leaving waste of fine-to-medium thickness. At each site, we collected nine topsoil samples $(0-5 \mathrm{~cm})$, giving a total of 36 . The plots were designed in sites of similar soil type, vegetation composition, and topographical characteristics (slope $<10 \%$ and north-east aspect). The severity of the wildfire of 2015 was classified as high in accordance with Úbeda et al. (2006), given that $100 \%$ of tree crowns were combusted.

\subsection{Laboratory methods}

Soil samples were dried to constant weight at room temperature (approx. $23^{\circ} \mathrm{C}$ ) for 7 days. To analyze aggregate stability (AS), the ten-drop impact (TDI) method (Low, 1954) was used. The samples 

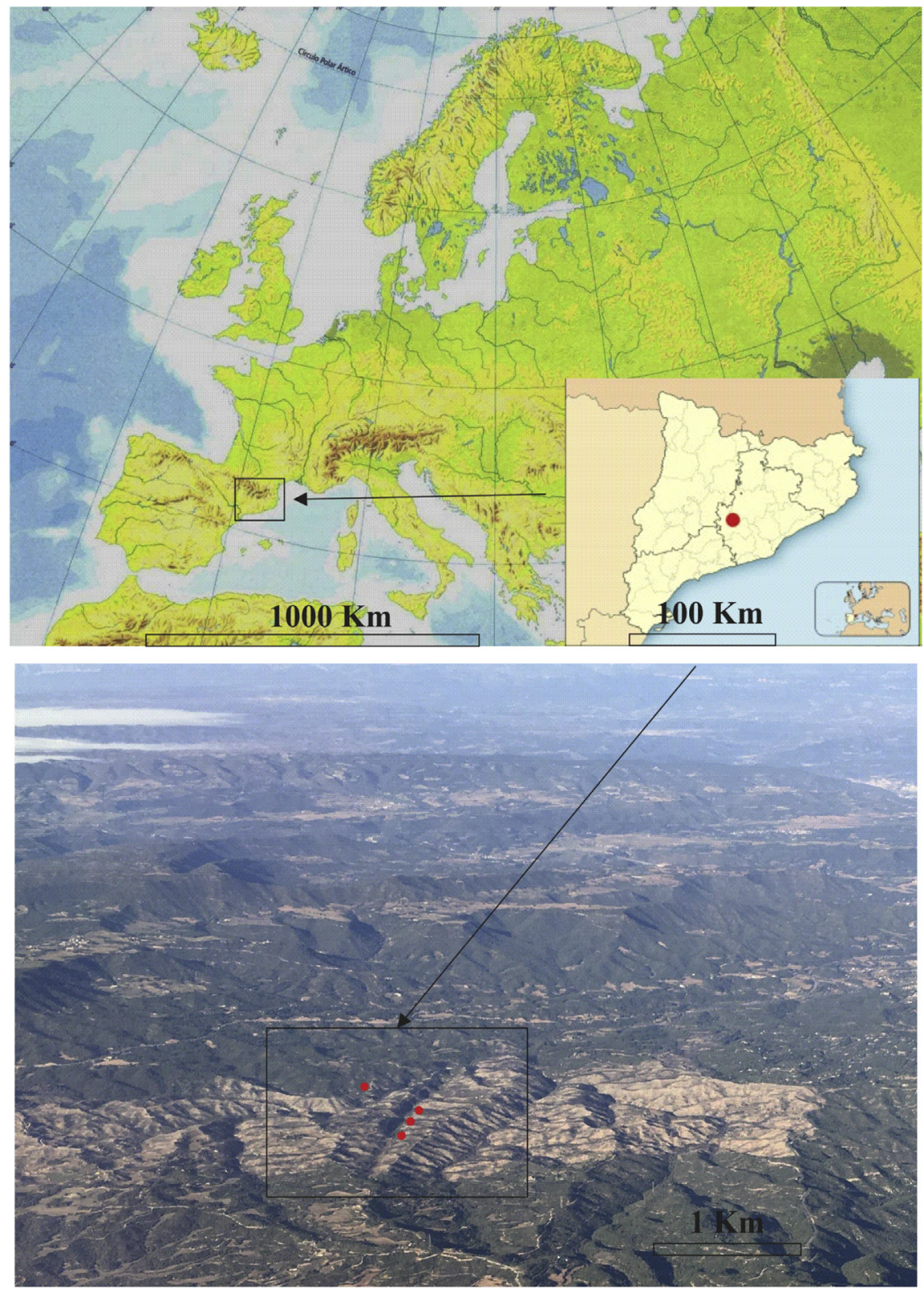

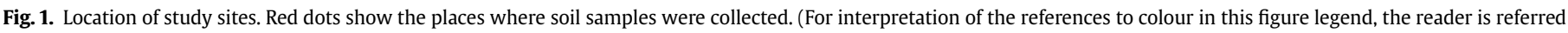
to the web version of this article.)

Table 1

Study sites, year of fire and year of management of studied sites.

\begin{tabular}{lll}
\hline Study sites & Years of fire/s & Date of management \\
\hline M05B & 1986 and 2015 & 2005 \\
M15B & 1986 and 2015 & 2015 (2 months before fire) \\
NMB & 1986 and 2015 & Not managed \\
Control & 1986 & Not managed \\
\hline
\end{tabular}

were sieved using a 4.8-mm mesh sieve. For each sample, ten airdried aggregates (between 4 and $4.8 \mathrm{~mm}$ ) were collected. A 2.8$\mathrm{mm}$ sieve was placed over the aggregates and they were subjected to the impact of ten drops of deionized water, from a droplet placed at a height of $1 \mathrm{~m}$. Each drop had a weight of $0.1 \pm 0.001 \mathrm{~g}$ and a diameter of $2.8 \mathrm{~mm}$. Aggregates were weighed before the test and the disaggregated material, which passed through the sieve during the test, was also weighed after drying at $105^{\circ} \mathrm{C}$ for $24 \mathrm{~h}$. The results are expressed as a percentage of the aggregate weight that remains stable after TDI as explained Úbeda et al. (1990).

To determine the other soil properties, the samples were sieved using a 2-mm mesh sieve. Total nitrogen content was analyzed with a Flash EA 112 Series (Thermo-Fisher Scientific, Milan). Data acquisition and calculations were carried out using Eafer 300 software (Thermo-Fisher Scientific, Milan) (Pereira et al., 2012). SOM and inorganic carbon were measured using the loss-onignition method described in Heiri et al. (2001). For each sample, $1 \mathrm{~g}$ of soil was pulverized and dried in a muffle furnace at $105^{\circ} \mathrm{C}$ for $24 \mathrm{~h}$. To determine SOM content, the dried samples were exposed to a temperature of $550{ }^{\circ} \mathrm{C}$ for $4 \mathrm{~h}$. Finally, to calculate soil inorganic carbon, the samples were subjected to a temperature of $950{ }^{\circ} \mathrm{C}$ for $2 \mathrm{~h}$. The results were expressed as percentages. Soil $\mathrm{pH}$ and EC were analyzed with deionized water. The amounts of extractable elements ( $\mathrm{Ca}, \mathrm{Mg}$, Na and $\mathrm{K}$ ) were analyzed using the method described by Knudsen et al. (1982). 
Each soil sample was kept under $4{ }^{\circ} \mathrm{C}$ to measure its microbiological parameters. Microbial biomass carbon $\left(\mathrm{C}_{\mathrm{mic}}\right)$ was extracted using the chloroform fumigation and extraction procedure (Vance et al., 1987). Basal soil respiration (BSR) was measured using a multiple sensor respirometer Micro-Oxymax (Anderson, 1982). Three indexes were calculated: $\mathrm{C}_{\text {mic }} / \mathrm{C}$ ratio, carbon mineralization coefficient $(\mathrm{BSR} / \mathrm{C})$ and metabolic quotient $\left(\mathrm{BSR} / \mathrm{C}_{\mathrm{mic}}\right.$ ) (MorugánCoronado et al., 2015).

\subsection{Statistical analysis}

Prior to conducting any statistical analyses, data normality and homogeneity were assessed using the Shapiro-Wilk and Levene's tests. If data followed the Gaussian distribution and respected the homogeneity of the variances, we applied a one-way ANOVA test; in those instances where the data did not satisfy normality and homogeneity requirements, we applied the non-parametric Kruskal-Wallis ANOVA test. If significant differences were identified at $\mathrm{p}<0.05$, a Tukey post-hoc test was applied in order to identify differences within treatments. A redundancy analysis (RDA) was carried out to identify the extent to which the variation in one set of variables accounts for the variation in another. The soil properties used in the RDA were AS, SOM content, TN, C/N, IC, pH, EC, extractable $\mathrm{Ca}, \mathrm{Mg}, \mathrm{Na}$, and $\mathrm{K}, \mathrm{C}_{\text {mic }}$, BSR and the three indexes: $\mathrm{C}_{\text {mic }}$ $\mathrm{C}, \mathrm{BSR} / \mathrm{C}$, and $\mathrm{BSR} / \mathrm{C}_{\text {mic }}$. Statistical analyses were carried out using SPSS 23.0 and CANOCO for Windows 4.5 software.

\section{Results and discussion}

\subsection{Soil physical and chemical properties}

Soil AS presented high values at all the sites ranging from 91.1 (M05B) to 95.9\% (Control) (Table 2). Significant differences were found between the study sites, with a slightly lower AS at M05B. However, the differences between their respective mean values were very low and cannot be considered relevant. Different patterns of AS behavior have been reported in burned soils in relation to different degrees of fire severity and soil type (Mataix-Solera et al., 2011). Here, the slightly lower values found at M05B could be due to the higher fire severity suffered at this site. The impact of this severity is apparent in other soil properties recorded at this site (see discussion below). Previous studies in the laboratory (BadiaVillas et al., 2014) and the field (Varela et al., 2015) have pointed to a decrease in AS in soils affected by high severity fires, which can be primarily attributed to SOM consumption. In other cases where inorganic constituents play an important role in AS, if high temperatures are registered in a soil, an increase in AS has been observed and attributed to mineralogical and micro-structural changes in the surface of soil aggregates (Jiménez-Pinilla et al., 2016). In our study, the differences observed were relatively very small.

TN and SOM were significantly higher in the NMB plot compared to the values recorded at M05B and the Control. Fire can reduce SOM content when high severity burning occurs (MataixSolera et al., 2002). In other cases, SOM has been found to increase as a result of the post-fire incorporation of partially burned material from charred vegetation into the soil (Caon et al., 2014; Knicker, 2007). Typically, high severity fires reduce TN and SOM in the period immediately after a fire because of the high temperatures reached in combustion (Certini et al., 2011; Mikita-Barbato et al., 2015; Vergnoux et al., 2011). However, if ash is deposited, then erosion is reduced; but, if ash is transported from other sites (Pereira et al., 2015b), an increase in TN and SOM can be expected. The gentle slope and the consequent accumulation of ash in the immediate post-fire period may have facilitated this incorporation.
Table 2

Descriptive statistics of physic-chemical characteristics. Different letters represent significant differences at a $\mathrm{p}<0.05 . \mathrm{N}=9$.

\begin{tabular}{|c|c|c|c|c|}
\hline Soil property & Study site & Mean & SD & $\mathrm{p}$ value \\
\hline \multirow[t]{4}{*}{ Aggregate Stability (\%) } & M05B & $91.10^{\mathrm{b}}$ & 3.80 & \multirow[t]{4}{*}{$* 1$} \\
\hline & M15B & $92.75^{\mathrm{a}, \mathrm{b}}$ & 3.98 & \\
\hline & NMB & $94.58^{\mathrm{a}, \mathrm{b}}$ & 3.60 & \\
\hline & Control & $95.85^{\mathrm{a}}$ & 2.01 & \\
\hline \multirow[t]{4}{*}{ Total Nitrogen (\%) } & M05B & $0.24^{\mathrm{b}}$ & 0.04 & \multirow[t]{4}{*}{$* * 1$} \\
\hline & M15B & $0.28^{\mathrm{a}, \mathrm{b}}$ & 0.07 & \\
\hline & NMB & $0.34^{\mathrm{a}}$ & 0.04 & \\
\hline & Control & $0.25^{\mathrm{b}}$ & 0.06 & \\
\hline \multirow[t]{4}{*}{ Soil Organic Matter (\%) } & M05B & $4.18^{\mathrm{b}}$ & 0.98 & \multirow[t]{4}{*}{$* 1$} \\
\hline & M15B & $5.07^{\mathrm{a}, \mathrm{b}}$ & 1.68 & \\
\hline & NMB & $5.87^{\mathrm{a}}$ & 0.66 & \\
\hline & Control & $4.15^{\mathrm{b}}$ & 0.77 & \\
\hline \multirow[t]{4}{*}{ Inorganic Carbon (\%) } & M05B & $5.77^{\mathrm{a}}$ & 0.14 & \multirow[t]{4}{*}{$* * * 2$} \\
\hline & M15B & $4.19^{b}$ & 0.20 & \\
\hline & NMB & $4.59^{\mathrm{b}}$ & 0.63 & \\
\hline & Control & $4.61^{\mathrm{b}}$ & 0.28 & \\
\hline \multirow[t]{4}{*}{$\mathrm{C} / \mathrm{N}$ ratio } & M05B & 17.70 & 1.87 & \multirow[t]{4}{*}{ n.s. ${ }^{1}$} \\
\hline & M15B & 17.67 & 1.75 & \\
\hline & NMB & 17.46 & 0.93 & \\
\hline & Control & 16.75 & 1.22 & \\
\hline \multirow[t]{4}{*}{$\mathrm{pH}$} & M05B & $8.28^{\mathrm{a}}$ & 0.25 & \multirow[t]{4}{*}{$* 1$} \\
\hline & M15B & $8.18^{\mathrm{a}, \mathrm{b}}$ & 0.17 & \\
\hline & NMB & $8.06^{\mathrm{b}, \mathrm{c}}$ & 0.04 & \\
\hline & Control & $7.88^{c}$ & 0.11 & \\
\hline \multirow[t]{4}{*}{$\mathrm{EC}(\mu \mathrm{S} / \mathrm{cm})$} & M05B & $187^{\mathrm{b}, \mathrm{c}}$ & 60.57 & \multirow[t]{4}{*}{$* * 2$} \\
\hline & M15B & $273^{\mathrm{a}, \mathrm{b}}$ & 119.49 & \\
\hline & NMB & $320^{a}$ & 58.92 & \\
\hline & Control & $149^{c}$ & 38.46 & \\
\hline \multirow[t]{4}{*}{ Extractable Ca (ppm) } & M05B & $17699^{c}$ & 1738.62 & \multirow[t]{4}{*}{$* 1$} \\
\hline & M15B & $19650^{\mathrm{a}, \mathrm{b}}$ & 1027.90 & \\
\hline & NMB & $20630^{a}$ & 1762.87 & \\
\hline & Control & $18613^{\mathrm{b}, \mathrm{c}}$ & 1366.75 & \\
\hline \multirow[t]{4}{*}{ Extractable Mg (ppm) } & M05B & $825^{\mathrm{b}}$ & 186.88 & \multirow[t]{4}{*}{$* * 2$} \\
\hline & M15B & $1157^{\mathrm{a}, \mathrm{b}}$ & 486.69 & \\
\hline & NMB & $1356^{\mathrm{a}}$ & 261.93 & \\
\hline & Control & $1093^{\mathrm{a}, \mathrm{b}}$ & 317.25 & \\
\hline \multirow[t]{4}{*}{ Extractable Na (ppm) } & M05B & 263 & 195.79 & \multirow[t]{4}{*}{ n.s. ${ }^{1}$} \\
\hline & M15B & 278 & 95.41 & \\
\hline & NMB & 204 & 52.24 & \\
\hline & Control & 288 & 83.68 & \\
\hline \multirow[t]{4}{*}{ Extractable K (ppm) } & M05B & $445^{\mathrm{a}}$ & 101.71 & \multirow[t]{4}{*}{$* * * 2$} \\
\hline & M15B & $467^{\mathrm{a}}$ & 69.24 & \\
\hline & NMB & $541^{\mathrm{a}}$ & 89.54 & \\
\hline & Control & $277^{\mathrm{b}}$ & 29.07 & \\
\hline
\end{tabular}

${ }^{1}$ One-way ANOVA, ${ }^{2}$ Kruskal-Wallis. Four different sampling plots. ${ }^{*} \mathrm{p}<0.05$ ${ }^{* *} \mathrm{p}<0.01,{ }^{* * *} \mathrm{p}<0.001$.

If we compare the sites burned in 2015, TN and SOM content values suggest M05B was exposed to higher fire severity.

In the case of IC, the values observed at M05B were significantly higher than those recorded at the other sites. This indicates that fire severity at this plot was slightly higher than that observed at NMB and M15B. Inorganic carbon or carbonate content in the soil or ash is a good indicator of fire severity. Typically, high severity fires produce ash with a high amount of carbonates (Pereira et al., 2012). Here, the high severity at the M05B plot can be attributed to the accumulation of dry biomass (for further discussion, see analysis of implications for forest management).

No significant differences were observed in the $\mathrm{C} / \mathrm{N}$ ratio between sites. Santin et al., 2016 observed high $\mathrm{C} / \mathrm{N}$ ratios in some burned plots attributable to high severity fires, but in our study there were no differences between the burned and unburned plots. Typically, wildfires mineralize the organic matter, reducing the soil $\mathrm{C} / \mathrm{N}$ ratio in comparison to that found at unburned sites (Volkova et al., 2014) as a consequence of ash being incorporated into the soil profile (Bodí et al., 2014). Here, this did not occur presumably because of the high fire severity observed, which produced ash of similar C/N ratios to that at unburned sites (De Baets et al., 2016). 
Soil pH values were significantly higher at M05B than they were at NMB and the Control. No significant differences were observed in these values between M05B and M15B, but the values were slightly higher at M05B, suggesting a higher fire severity at M05B. It is widely reported that after a high severity fire, soil $\mathrm{pH}$ increases in relation to the values found at unburned sites (Ulery et al., 1993). Jimenez-Esquilin et al. (2007) observed an increase in soil pH after a slash pile burning. This is attributed to the ash oxides and hydroxides released in solution (Bodí et al., 2014). pH levels increase with fire temperature/severity (Pereira et al., 2012), a finding corroborated by our study. The increase in $\mathrm{pH}$ is inversely related to the fall in TN and SOM. Soils affected by a high severity wildfire, followed by the incorporation of white ash, increase their $\mathrm{pH}$ levels. However, TN and SOM fall as a consequence of the high temperatures experienced (Certini et al., 2011; Mataix-Solera and Guerrero, 2007). EC was significantly higher in the burned plots, which is due to the release of anions and major cations in solution from the mineralized organic matter (Knicker, 2007). Significant differences were also identified between pre-fire treatments. The NMB plot released a significantly higher amount of salts than were released by M05B, which again may be due to the high fire severity recorded at M05B. Previous studies report that in soils and litter heated at very high temperatures, there is a decrease in EC (Badia and Marti, 2003; Úbeda et al., 2009), which is attributable to the reduced solubility of soils richer in carbonates that regulate the amount and type of nutrients in solution. The solubility of carbonates decreases with increasing $\mathrm{pH}$. In addition, the carbonate surfaces with a $\mathrm{pH}$ between 7 and 10 are negatively charged, thus increasing their capacity to attract cations by sorption onto their surfaces (Pereira et al., 2012). For these reasons, EC was significantly lower at M05B than it was at the NMB site.

Extractable Ca was significantly higher at NMB and M15B than it was at the Control site (Table 2), which again can be attributed to ash incorporation, as observed in previous studies carried out in soils affected by high severity fires (Badia et al., 2014; Dzwonko et al., 2015; Rhoades et al., 2004). No significant differences in extractable Na were observed across the sites. However, the concentration of extractable $\mathrm{K}$ was significantly higher in the burned plots compared to levels reported at the Control. The increase in extractable $\mathrm{K}$ associated with high severity fires has been reported elsewhere (Bates and Davies, 2017; Murphy et al., 2006; Simard et al., 2001).

\subsection{Soil microbiological properties}

MBC was significantly higher at NMB than at the Control site (Table 3 ). Previous studies reported that $C_{\text {mic }}$ levels normally fall in soils affected by wildfires compared to those observed in unburned soils. This can be attributed to the direct impact of soil heating, which reduces the soil microbe population (Barcenas-Moreno et al., 2016; Garcia-Orenes et al., 2017; Lombao et al., 2015). Some studies failed to identify any differences between unburned soils and those affected by high severity fires (Fultz et al., 2016; Holden et al., 2015), while others observed significant differences (Kumar Singh et al., 2017). In our case, we do not measure the direct impact of fire, rather we examine direct and indirect effects after the event. The significantly high $\mathrm{C}_{\mathrm{mic}}$ at $\mathrm{NMB}$ compared to that at the Control can be attributed to the higher SOM content, which is known to have a positive effect on microbial populations (Blonska et al., 2017; Goberna et al., 2006; Pérez-Bejarano et al., 2010; Wolinska et al., 2015; Zornoza et al., 2007). In many cases, in the immediate postfire period, there is an ephemeral increase in the amount of soluble carbon attributable to the cells of dead microorganisms (Mataix Solera et al., 2009). This can lead to a short-term increase in microbial activity, but one that falls soon after the consumption of this
Table 3

Descriptive statistics of microbiological characteristics. Different letters represent significant differences at a $\mathrm{p}<0.05 . \mathrm{n}=9$.

\begin{tabular}{lllll}
\hline Soil property & Study site & Mean & SD & p value \\
\hline Cmic & M05B & $983.89^{\mathrm{a}, \mathrm{b}}$ & 352.87 & $* 1$ \\
& M15B & $925.13^{\mathrm{a}, \mathrm{b}}$ & 221.65 & \\
& NMB & $1240.30^{\mathrm{a}}$ & 238.02 & \\
BSR & Control & $827.70^{\mathrm{b}}$ & 371.02 & $* 1$ \\
& M05B & $2.15^{\mathrm{b}}$ & 0.86 & $* 1$ \\
& M15B & $1.78^{\mathrm{b}}$ & 0.83 & \\
& NMB & $2.10^{\mathrm{b}}$ & 0.99 & \multirow{2}{*}{ n.s. ${ }^{1}$} \\
Cmic/C & Control & $3.34^{\mathrm{a}}$ & 0,73 & \\
& M05B & 239.47 & 77.38 & \multirow{2}{*}{$* * * 1$} \\
& M15B & 187.52 & 28.81 & \\
BSR/C & NMB & 211.78 & 33.35 & \\
& Control & 195.22 & 57.74 & \\
& M05B & $0.5056^{\mathrm{b}}$ & 0.1076 & \\
& M15B & $0.3668^{\mathrm{b}}$ & 0.1554 & \\
BSR/Cmic & NMB & $0.3615^{\mathrm{b}}$ & 0.1740 & \\
& Control & $0.8087^{\mathrm{a}}$ & 0.1418 & \\
& M05B & $0.0023^{\mathrm{b}}$ & 0.0008 & \\
& M15B & $0.0020^{\mathrm{b}}$ & 0.0010 & \\
& NMB & $0.0018^{\mathrm{b}}$ & 0.0009 & \\
& Control & $0.0044^{\mathrm{a}}$ & 0.0013 & \\
\hline
\end{tabular}

${ }^{1}$ One-way ANOVA, ${ }^{2}$ Kruskal-Wallis. Four different sampling plots. ${ }^{*} \mathrm{p}<0.05$, ${ }^{* *} \mathrm{p}<0.01,{ }^{* * *} \mathrm{p}<0.001$.

fraction (Muñoz-Rojas et al., 2016).

BSR and the BSR/C and BSR/ $C_{\text {mic }}$ ratios were significantly higher at the Control than they were at the other sites. No significant differences were identified in the $C_{\text {mic }} / C$ ratio (Table 3 ). This is in agreement with previous studies that identified a marked reduction in BSR (Lopez-Serrano et al., 2016; Vega et al., 2013), BSR/C (Vega et al., 2013) and BSR/C $C_{\text {mic }}$ (Hernández et al., 1997) at sites affected by high severity fires in comparison to the values reported at unburned sites. Guo et al. (2010) observed significantly higher values of BSR at their control site than at the clear-cut and slashburned sites. Despite the higher values of $C_{\text {mic }}$ at the fire-affected sites, we identified a significantly higher BSR at the Control plot, which shows that soil respiration is not always positively correlated with microbial biomass (Guo et al., 2015). The reduction in microbial activity at the burned sites may be attributed to the highly recalcitrant charcoal that is more resistant to microbial decomposition (Knicker et al., 2013). Microbial activity may also be perturbed by the release of organic pollutants and heavy metals (Vega et al., 2013). The significantly lower metabolic quotient $\left(B S R / C_{\text {mic }}\right)$ at the burned sites confirms the conclusion drawn above that microbial activity was lower and failed to recover from the fire disturbance (Hernández et al., 1997).

\subsection{Multivariable analysis}

The RDA enables us to determine whether in general the soil properties of the treated sites differ because of the effects of wildfire. Factor- 1 in the RDA explains $32.4 \%$ of the variance while Factor-2 explains $29.7 \%$, that is, a total of $62.1 \%$. The variables with the highest explanatory capacity are IC, $\mathrm{pH}$ and extractable $\mathrm{K}$, while those with the lowest are extractable $\mathrm{Na}, \mathrm{C} / \mathrm{N}$ ratio and $\mathrm{C}_{\text {mic }}$. Thus, the RDA clearly separates the pre-fire management sites from the control plot and highlights the different behavior of the variables. $\mathrm{BSR}, \mathrm{AS}, \mathrm{BSR} / \mathrm{C}$ and $\mathrm{BSR} / \mathrm{C}_{\text {mic }}$ were closely associated with the Control site; SOM, TN, EC major cations, $\mathrm{K}$ and $\mathrm{Cmic}$ were closely associated with M15B and NMB; and, IC and $\mathrm{C}_{\text {mic }} / \mathrm{C}$ were associated with M05B (Fig. 2).

\subsection{Implications for forest management - a discussion}

Post-fire management, especially salvage logging, is 
controversial owing to its potentially negative effects, being implemented when major efforts are required to remedy the impact of wildfires. Previous studies observed that salvage logging has major negative impacts on soil properties in the short- (Donato et al., 2006; Garcia-Orenes et al., 2017; Wagenberger et al., 2016), medium- (Wagenberger et al., 2015) and long-term (Johnson et al., 2005). Indeed, this management practice has also been reported as having a marked effect on plant recovery and succession (Boucher et al., 2014; Hernández-Hernández et al., 2017). However, very little attention has been paid to preventive methods aimed at reducing forest fuel accumulation, but it is critical that they be taken into consideration in forest management plans, especially in fire-prone sites, such as the Mediterranean (Francos et al., 2016b; Leverkus et al., 2014; Marañon-Jimenez et al., 2013; Piqué et al., 2011). The 2015 wildfire studied here had more negative impacts on the soil properties of the plot managed in 2005 than it did on the plot not exposed to any management and the plot managed in 2015. Despite the high severity of the fire in all treatments, the M05B plot presented the highest soil $\mathrm{pH}$ and IC, indicating that the impact here was more detrimental than elsewhere. The high TN, SOM, EC, extractable $\mathrm{Ca}$ and $\mathrm{Mg}$ values recorded at the $\mathrm{NMB}$ plot in relation to the values observed at M05B were evidence that, three months after the fire, the plot that had not undergone any management was in a better position to begin regeneration than was the plot managed in 2005. According to the impacts on the soil properties studied here, the three sites exposed to the effects of this high severity fire can be ranked in the following descending order: M05B > M15B > NMB. The plot managed in 2005 was the site where the effects were greatest because of the greater accumulation of dead fuel. Some authors argue that forest management is essential for reducing the impact of fire on soils (Fernandes et al., 2013; Tempel et al., 2014); however, here, the fact that the vegetation had been cut 10 years previously meant that prior to the fire

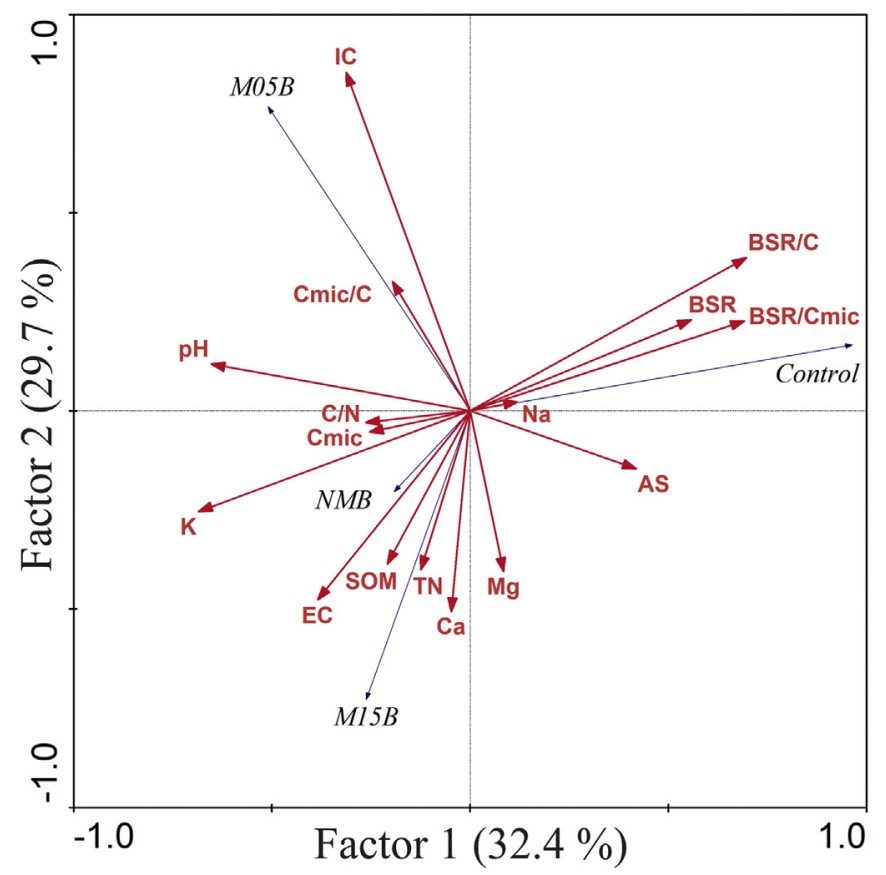

Fig. 2. RDA about the relation between Factor 1 and 2. Aggregate Stability (AS), Soil Organic Matter (SOM) content, Total Nitrogen (TN), Carbon/Nitrogen ratio $(\mathrm{C} / \mathrm{N})$, Inorganic Carbon (IC), pH, Electrical Conductivity (EC), extractable Calcium (Ca), Magnesium (Mg), Sodium (Na), Potassium (K), Microbial Biomass Carbon $\left(\mathrm{C}_{\mathrm{mic}}\right)$ and Basal Soil Respiration (BSR) and three different index $C_{\text {mic }} / C$ ratio, carbon mineralization coefficient $(B S R / C)$ and metabolic quotient $\left(B S R / C_{\text {mic }}\right)$. the wood was dry and so the fire burned with greater intensity. Fuel type has been shown to have implications for flammability, the response to fire temperatures and, ultimately, fire severity (Dimitrakopoulos and Panov, 2001; Úbeda et al., 2009). Given our results, we hypothesize that the combustible fuel present at the NMB plot before the fire was less flammable. But, further research is needed on this point. Overall, for the ecosystem studied here, the pre-fire NMB option was the one with least impact and, in some instances, it had positive impacts on certain soil properties. Further studies are underway in these sites aimed at assessing mediumand long-term effects and should dissipate any doubts caused by these initial results. It is clearly critical to have better information about the impact of wildfires in relation to different pre-fire management practices in the immediate post-fire period, since this is when fire brings about the most significant changes in soil properties (Caon et al., 2014; Francos et al., 2016a; Wang et al., 2014). It is our contention that pre-fire management represents a good option for preventing fires, but here the fact that after clear-cutting the dead vegetation was left to accumulate over the soil surface created a high fuel density resulting in a higher fire intensity when the wildfire broke out.

\section{Conclusions}

Forest management practices, such as clear cutting a site some years prior to or only a few months before a wildfire event fire (as reported herein), affect soil properties. Not clearing the cut vegetation from the soil surface affects the severity of the fire and induces more changes in soil properties. However, the differences observed across our study sites were not sufficiently significant to conclude that this is a detrimental treatment. On balance, we recommend this treatment as a way of preventing the outbreak of new forest fires, but large accumulations of cut vegetation covering the soil surface should be avoided so as to reduce fire severity in potential medium-to long-term episodes of wildfire. Clearly, further studies are needed to analyze the effect of clear-cutting management practices on soil properties to ensure the implementation of appropriate forest management and to determine if differences between treated and untreated sites increase or disappear over time.

\section{Acknowledgments}

This study was supported by the POSTFIRE Project (CGL201347862-C2-1 and 2-R) and the POSTFIRE_CARE Project (CGL201675178-C2-2-R [AEI/FEDER, UE]), financed by the Spanish Research Agency (AIE) and the European Union through European Funding for Regional Development (FEDER) and the FPU Program (FPU 014/ 00037) of the Ministry of Education, Culture and Sports and Program 2014SGR825 of the Generalitat de Catalunya. We also wish to thank our scientific and technical services for analyses of certain soil parameters and for the English revision of this manuscript. We also want to thank the Diputación de Barcelona for facilitating access to the study site to complete the fieldwork. The authors acknowledge the valuable suggestions of anonymous reviewers who have contributed significantly to the quality of this study.

\section{References}

Alcañiz, M., Outeiro, L., Francos, M., Farguell, J., Úbeda, X., 2016. Long-term dynamics of soil chemical properties after a prescribed fire in a Mediterranean forest (Montgrí Massif, Catalonia, Spain). Sci. Total Environ. 572, 1329-1335.

Anderson, J.P.E., 1982. Soil respiration. In: Dinauer, R.C. (Ed.), Methods of Soil Analysis. Part 2. Chemical and Microbiological Properties. ASA, SSSA, Madison, Wisconsin (USA), pp. 831-871.

Andersson, M., Michelsen, A., Jensen, M., Kjoller, A., 2004. Tropical savannah 
woodland: effects of experimental fire on soil microorganisms and soil emissions of carbon dioxide. Soil Biol. Biochem. 36, 849-858.

Arcenegui, V., Mataix-Solera, V., Guerrero, C., Zornoza, R., Mataix-Beneyto, J., GarcíaOrenes, F., 2008. Immediate effects of wildfire on water repellency and aggregate stability in Mediterranean calcareous soils. Catena 74, 219-226.

Augustine, D.J., Brewer, P., Blumenthal, D.M., Derner, J.D., von Fisher, J.C., 2014 Prescribed fire, soil inorganic nitrogen dynamics, and plant responses in a semiarid grassland. J. Arid Environ. 104, 59-66.

Badia, D., Marti, C., 2003. Plant ash and heat intensity effects on chemical and physical properties of two contrasting soils. Arid Land Res. Manag. 17, 23-41.

Badia, D., Marti, C., Aguirre, T., Aznar, J.M., Gonzalez-Perez, J.A., De la Rosa, J.M. Leon, J., Ibarra, P., Echeverria, T., 2014. Wildfire effects on nutrients and organic carbon of a Rendzic Phaeozem in NE Spain: changes at cm-scale topsoil. Catena $113,267-275$

Badia-Villas, D., Gonzalez-Perez, J.A., Aznar, J.M., Arjona-Gracia, B., Marti-Dalmau, C. 2014. Changes in water repellency, aggregation and organic matter of a mollic horizon burned in laboratory: soil depth affected by fire. Geoderma 213, 400-407.

Barcenas-Moreno, G., Garcia-Orenes, F., Mataix-Solera, J., Mataix-Beneyto, J., 2016. Plant community influence on soil microbial response after wildfire in Sierra Nevada National Park. Sci. Total Environ 573, 1265-1274.

Bates, J.D., Davies, K.W., 2017. Effect of conifer treatments on soil nutrients availability and plant composition in sagebrush steppe. For. Ecol. Manage 400, $631-644$.

Blonska, E., Lasota, J., Gruba, P., 2017. Enzymatic activity and stabilization of organic matter in soil with different detritus inputs. Soil Sci. Plant Nutr. 63, 242-247.

Bodí, M., Martin, D., Santin, C., Balfour, V., Doerr, S.H., Pereira, P., Cerdà, A., MataixSolera, J., 2014. Wildland fire ash: production, composition and eco-hydrogeomorphic effects. Earth Sci. Rev. 130, 103-127.

Bond, M.M., Van Wilgen, B.W., 1996. Fire and Plants. Population and Community Biology Series 14. Chapman \& Hall.

Boucher, D., Gauthier, S., Noel, J., Greene, D.F., Bergeron, Y., 2014. Salvage logging affects early-post fire tree composition in Canadian boreal forest. For. Ecol Manage 325, 118-127.

Caon, L., Vallejo, R., Coen, R.J., Geissen, V., 2014. Effects of wildfire on soil nutrients Mediterranean ecosystems. Earth Sci. Rev. 139, 47-58.

Certini, G., 2005. Effects of fire on properties of forest soils: a review. Oecologia 143, $1-10$.

Certini, G., 2014. Fire as a soil forming factor. Ambio 43, 191-195.

Certini, G., Nocentini, C., Knicker, H., Arfaioli, P., Rumpel, C., 2011. Wildfire effects on soil organic matter quantity and quality in two fire-prone Mediterranean pine forests. Geoderma 167-168, 148-155.

Cochrane, M.A., Moran, C.J., Wimberly, M.C., Baer, A.D., Finney, M.A. Beckendorf, K.L., Eidenshink, J., Zhu, Z., 2012. Estimation of wildfire size and risk changes due to fuels treatments. Int. J. Wildland Fire 21, 357-367.

Corona, P., Ascoli, D., Barbati, A., Bovio, G., Colangelo, G., Elia, M., Garfi, V., Iovino, F. Lafortezza, R., Leone, V., Lovreglio, R., Marchetti, M., Marchi, E., Menguzzato, G. Nocentini, S., Picchio, R., Portoghesi, L., Puletti, N., Sanesi, G., Chianucci, F., 2015 Integrated forest management to prevent wildfires under Mediterranean environments. Annals of Silvicultural Research 39, 1-22.

De Baets, S., van de Weg, M.J., Lewis, R., Steinberg, N., Meersmans, J., Quine, T.A. Shaver, G.R., Hartley, I.P., 2016. Investigating the controls on soil organic matter decomposition in tussock tundra soil and permafrost after fire. Soil Biol. Biochem. 99, 108-116.

De Marcos, A., Gentile, A.E., Arena, C. De Santo, A.V., 2005. Organic matter, nutrient content and biological activity in burned and unburned soils of a Mediterranean maquis area of Southern Italy. Int. J. Wildland Fire 14, 365-377.

Dimitrakopoulos, A.P., Panov, P.I., 2001. Pyric properties of some dominant Mediterranenan vegetation species. Int. J. Wildland Fire 10, 23-27.

Donato, D.C., Fontaine, J.B., Campbell, J.L., Robinson, W.D., Kauffman, J.B., Law, B.E. 2006. Post-wildfire logging hinders regeneration and increases fire risk. Science 311, 352.

Dzwonko, Z., Loster, S., Gawronski, S., 2015. Impact of fire severity on soil properties and the development of tree and shrub species in a Scots pine moist forest site in Southern Poland. For. Ecol. Manage 342, 56-63.

Fernandes, P.M., Davies, G.M., Ascoli, D., Fernández, C., Moreira, F., Rigolot, E., Stoof, C.R., Vega, J.A., Molina, D., 2013. Prescribed burning in southern Europe: developing fire management in a dynamic landscape. Front. Ecol. Environ. 11, 4-14.

Francos, M., Pereira, P., Alcañiz, M., Mataix-Solera, J., Úbeda, X., 2016a. Impact of an intense rainfall event on soil properties following a wildfire in a Mediterranean environment (North-East Spain). Sci. Total Environ. 572, 1353-1362.

Francos, M., Úbeda, X., Pereira, P., Alcañiz, M., 2018. Long-term impact of wildfire on soils exposed to different fire severities. A case study in Cadiretes Massif (NE Iberian Peninsula). Sci. Total Environ. 615, 664-671.

Francos, M., Úbeda, X., Tort, J. Panareda, J.M., Cerdà, A., 2016b. The role of forest fire severity on vegetation recovery after 18 years. Implications for forest management of Quercus suber L. in Iberian Peninsula. Global Planet. Change 145, $11-16$.

Fultz, L.M., Moore-Kucera, J., Dathe, J., Davinic, M., Perry, G., Wester, D. Schwink, D.W., Rideout-Hanzak, S., 2016. Forest wildfire and grassland prescribed fire effects on soil biogeochemical process and microbial communities: two case studies in the semi-arid Southwest. Appl. Soil Ecol. 99, 118-128.

Garcia-Orenes, F., Arcenegui, V., Chrenkova, K., Mataix-Solera, J., Jara-Navarro, A.B., Torres, M.P., 2017. Effects of salvage logging on soil properties and vegetation recovery in a fire affected Mediterranean forest: a two year monitoring research. Sci. Total Environ. 586, 1057-1065.

Guo, J., Yank, Y., Chen, G., Xie, J., Gao, R., Qian, W., 2010. Effects of clear-cutting and slash burning on soil respiration in Chinese fir and evergreen broadleaved forests in mid-subtropical China. Plant Soil 333, 249-261.

Goberna, M., Sánchez, J., Pascual, A.J., García, C., 2006. Surface and subsurface organic carbon, microbial biomass and activity in a forest soil sequence. Soil Biol. Biochem. 38, 2233-2243.

González-Pérez, J.A., González-Vila, F.J., Almendros, G., Knicker, H., 2004. The effect of fire on soil organic matter-a review. Environ. Int. 30, 855-870.

Gordillo-Rivero, A.J., García-Moreno, J., Jordán, A., Zavala, L., Granja-Martins, F.M., 2014. Fire severity and Surface rock fragments cause patchy distribution of soil water repellency and infiltration rates after burning. Hydrol. Process. 28, $5832-5843$

Guo, J., Chen, G., Xie, J., Yang, Z., Yang, Y., 2015. Effect of heat disturbance on microbial respiration in Chinese fire (Cunninghamia lancelota) forest soils. J. Food Res. 26, 933-939.

Heiri, O., Lotter, A.F., Lemcke, G., 2001. Loss on ignition as a method for estimating organic and carbonate content in sediments: reproducibility and comparability of results. J. Paleolimnol. 5, 101-110.

Hernández-Hernández, R., Castro, J., Del Arco Aguilar, M., Fernández-López, A.B., González-Mancebo, M., 2017. Post-fire salvage logging imposes a new disturbance that retards succession: the case of Bryophite communities in Macaronesian Laurel Forest. Forests 8, 252. https://doi.org/10.3390/f8070252.

Hernández, T., García, C., Reinhardt, I., 1997. Short-term effect of wildfire on the chemical, biochemical and microbiological properties of Mediterranean pine forest soils. Biol. Fertil. Soils 25, 109-116.

Holden, S.R., Berhe, A.A., Treseder, K.K., 2015. Decreases in soil moisture and organic matter quality suppress decomposition following a boreal forest fire. Soil Biol. Biochem. 87, 1-9.

Inbar, A., Lado, M., Sternberg, M., Tenau, H., Ben-Hur, M., 2014. Forest fire effects on soil chemical and physicochemical properties, infiltration, runoff, and erosion in a semiarid Mediterranean region. Geoderma 221-222, 131-138.

Jimenez-Esquilin, A.E., Stromberger, M.E., Massman, W.J., Frank, J.M., Shepperd, W.D., 2007. Microbial community structure and activity in a Colorado Rocky Mountain forest soil scarred by slash pile burning. Soil Biol. Biochem. 39, 1111-1120.

Jiménez-Pinilla, P., Mataix-Solera, J., Arcenegui, V., Delgado, R., Martin-García, J.M., Lozano, E., Martínez-Zavala, L., Jordán, A., 2016. Advances in the knowledge of how heating can affect aggregate stability in Mediterranean soils: a XDR and SEM-EDX approach. Catena 147, 315-324.

Johnson, D.W., Murphy, J.F., Susfalk, R.B., Caldwell, T.G., Miller, W.W., Walker, R.F., Powers, R.F., 2005. The effects of wildfire, salvage logging, and post-fire N-fixation on the nutrient budgets of a Sierran forest. For. Ecol. Manag 220,155-165.

Keeley, J.E., 2009. Fire intensity, fire severity and burn severity: a brief review and suggested usage. Int. J. Wildland Fire 18, 116-126.

Keeley, J.E., Bond, W.J., Bradstock, R.A., Pausas, J.G., Rundel, P.W., 2012. Fire in Mediterranean Ecosystems. Cambridge University Press, p. 515.

Kennard, D.K., Gholz, H.L., 2001. Effects of a high-and low-intensity fires on soil properties and plant growth in a Bolivian dry forest. Plant Soil 234, 119-129.

Knicker, H., 2007. How does fire affect the nature and stability of soil organic nitrogen and carbon? A review. Biogeochemistry 85, 91-118.

Knicker, H., Gonzalez-Vila, F.J., Gonzalez-Vasquez, R., 2013. Biodegradability of organic matter in fire-affected mineral soils of Southern Spain. Soil Biol. Biochem. 56, 31-39.

Knudsen, D., Petersen, G.A., Pratt, P.F., 1982. Lithium, sodium and potassium. In: Dinauer, R.C. (Ed.), Methods of Soil Analysis. Part 2. Chemical and Microbiological Properties. ASA, SSSA Madison, Wisconsin (USA), pp. 225-246.

Kumar Singh, A., Kushwaha, M., Rai, A., Singh, N., 2017. Changes in soil microbial response across year following a wildfire in a tropical dry forest. For. Ecol. Manage 391, 458-468.

Leverkus, A.B., Lorite, J., Navarro, F.B., Sánchez-Cañete, E.P. Castro, J., 2014. Post-fire salvage logging alters species composition and reduces cover richness and diversity in Mediterranean plant communities. J. Environ. Manag. 133, 323-331.

Liu, X., Chen, C.R., Hughe, J.M., Wang, W.J., Lewis, T., 2017. Temporal changes rather than long-term repeated burning predominately control the shift in the abundance of soil denitrifying community in an Australian Sclerophyl Forest. Microb. Ecol. https://doi.org/10.1007/s00248-016-0894-6.

Lombao, A., Barreiro, A., Carballas, T., Fonturbel, M.T, Martin, A., Vega, J.A., Fernandez, C., Diaz-Ravina, M., 2015. Changes in soil properties after a wildfire in Fragas do Eume Natural Park (Galicia, NW Spain). Catena 135, 409-418.

Lopez-Serrano, F.R., Rubio, E., Dadi, T., Moya, D., Andres-Abellan, M., GarciaMorote, F.A., Miettinen, H., Martinez-Garcia, E., 2016. Influence of recovery from wildfire and thinning on soil respiration of a Mediterranean mixed forest. Sci. Total Environ. 573, 1217-1231.

Low, A.J., 1954. The study of soil structure in the field and in the laboratory. J. Soil Sci. 5, 57-74.

Marañon-Jimenez, S., Castro, J., Querejeta, J.I., Fernandez-Ondono, E., Allen, C.D., 2013. Post-fire wood management alters water stress, growth, and performance of pine regeneration in a Mediterranean Ecosystem. For. Ecol. Manage 308, 231-239.

Martín-Alcón, S., Coll, L., 2016. Unraveling the relative importance of factor driving post-fire regeneration trajectories in non-serotinous Pinus nigra forest. For. Ecol. Manage 361, 13-22.

Mataix-Solera, J., Guerrero, C., 2007. Efectos de los incendios forestales sobre las 
propiedades edáficas. In: Mataix-Solera, J. (Ed.), Incendios forestales, suelo y erosión hídrica, Caja de Ahorros del Mediterráneo CEMACAM. Alcoi, pp. 5-40. Mataix-Solera, J., Gómez, I., Navarro-Pedreño, J., Guerrero, C., Moral, R., 2002. Soil organic matter and aggregates affected by wildfire in a Pinus halepensis forest in a Mediterranean environment. Int. J. Wildl. Fire 11, 107-114.

Mataix Solera, J., Guerrero, C., Garcia-Orenes, F., Barcenas, G.M., Torres, M.P., 2009. Forest fire effects on soil microbiology. In: Cerda, A., Robichaud, P.R. (Eds.), Fire Effects on Soils and Restoration Strategies. Science Publishers, Enfield (NH), pp. 133-175.

Mataix-Solera, J., Cerdà, A., Arcenegui, V., Jordan, A., Zavala, L.M., 2011. Fire effects on soil aggregation. Earth Sci. Rev. 109, 44-60.

Mikita-Barbato, R.A., Kelly, J.J., Tate III, R.L., 2015. Wildfire effects on the properties and microbial community structure of organic horizon soils in the New Jersey Pinelands. Soil Biol. Biochem. 86, 67-76.

Morugán-Coronado, A., García-Orenes, F., Cerdà, A., 2015. Changes in soil microbial activity and physicochemical properties in agricultural soils in Eastern Spain. J. Soil Sci. https://doi.org/10.3232/SJSS.2015.V5.N3.02, 5-3.

Muñoz-Rojas, M., Erickson, T.E., Martini, D., Dixon, K.W., Merrit, D.J., 2016. Soil physicochemical and microbiological indicators of short, medium and long term post-fire recovery in semi-arid ecosystems. Ecol. Indic 63, 14-22.

Murphy, J.D., Johnson, D.W., Miller, W.W., Walker, R.F., Carroll, E.F., Blank, R.R., 2006. Wildfire effects on soil nutrients and leaching in a Tahoe Basin Watersheed. J. Environ. Qual. 35, 479-489.

Panareda-Clopés, J.M., Nuet-Badia, J., 1993. Tipología y cartografía corológica de las plantas vasculares de Montserrat (Cordillera Prelitoral Catalana). Rev. Geogr. 27, 33-58.

Pereira, P., Cerdà, A., Martin, D., Úbeda, X., Depellegrin, D., Novara, A., MartínezMurillo, J.F., Brevik, E.C., Menshov, O., Comino, J.R., Miesel, J., 2017. Short-term low-severity spring grassland fire impacts on soil extractable elements and soil ratios in Lithuania. Sci. Total Environ. 578, 469-475.

Pereira, P., Jordan, A., Martin, D., Cerdà, A., 2015a. The role of ash in fire-affected ecosystems. Catena 135, 337-339.

Pereira, P., Cerdà, A., Úbeda, X., Mataix-Solera, J., Arcenegui, V., Zavala, L., 2015b. Modelling the impacts of wildfire on ash thickness in a short-term period. Land Degrad. Dev. 26, 180-192.

Pereira, P., Rein, G., Martin, D., 2016. Past and present post-fire environments. Sci. Total Environ. 573, 1275-1277.

Pereira, P., Úbeda, X., Martin, D., 2012. Fire severity effects on ash chemical composition and water-extractable elements. Geoderma 191, 105-114.

Pereira, P., Úbeda, X., Martin, D., Mataix-Solera, J., Cerdà, A., Burguet, M., 2014a. Wildfire affect on extractable in ash from Pinus pinaster forest in Portugal. Hydrol. Process. 28, 2681-2690.

Pereira, P., Úbeda, X., Martin, D.A., Mataix-Solera, J., Oliva, M., Novara, A., 2014b. Short-term spatio-temporal spring grassland fire effects on soil colour, organic matter and water repellency in Lithuania. Solid Earth 5, 209-225.

Pérez-Bejarano, A., Mataix-Solera, J., Zornoza, R., Guerrero, C., Arcenegui, V., MataixBeneyto, J., Cano-Amat, S., 2010. Influence of plant species on physcial, chemical and biological soil properties in Mediterranean forest soil. Eur. J. For. Res. 129, $15-24$.

Piqué, M., Castellnou, M., Valor, T., Pagés, J., Larrañaga, A., Miralles, M., Cervera, T., 2011. Integració del risc de grans incendis forestals (GIF) en la gestió forestal: Incendis tipus i vulnerabilitat de les estructures forestals al foc de capçades. Sèrie: Orientacions de gestió forestal sostenible per a Catalunya (ORGEST). Centre de la Propietat Forestal. Departament d'Agricultura, Ramaderia, Pesca, Alimentació i Medi Natural. Generalitat de Catalunya.

Rhoades, C.C., Meier, A.J., Rebertus, A.J., 2004. Soil properties in fire consumed log burnout openings in a Missouri oak Savanna. For. Ecol. Manag. 192, 277-284.

Santin, C., Doerr, S.H., Merino, A., Bryant, R., Loader, N.J., 2016. Forest floor chemical transformations in a boreal forest fire and their correlations with temperature and heating duration. Geoderma 264, 71-80.

Simard, A., 1991. Fire severity, changing scales, and how things hang together. Int. J. Wildland Fire 1, 23-34.

Simard, D.G., Fyles, J.W., Pare, D., Nguyen, T., 2001. Impacts of clearcut harvesting and wildfire on soil nutrient status in Quebec boreal forest. Can. J. Soil Sci. 81,
229-237.

Soil Survey Staff, 2014. Keys to Soil Taxonomy, twelfth ed. USDA-Natural Resources Conservation Service, Washington, DC.

Tempel, D.J., Gutierrez, R.J., Whitmore, S.A., Reetz, M.J., Stoelting, R.E., Berigan, W.J., Seamans, M.E., Peery, M.Z., 2014. Effects of forest management on California Spotted Owls: implications for reducing wildfire risk in fire-prone areas. Ecol. Appl. 24, 2089-2106.

Tessler, N., Sapir, Y., Wittenberg, L., Greenbaum, N., 2016a. Recovery of Mediterranean vegetation after recurrent forest fires: insight from the 2010 forest fire on Mount Carmel, Israel. Land Degrad. Dev. 27, 1424-1431.

Tessler, N., Wittenberg, L., Greenbaum, N., 2016b. Vegetation cover nd species richness after recurrent forest fires in Eastern Mediterranean ecosystem of Mount Carmel, Israel. Sci. Total Environ. 572, 1395-1402.

Úbeda, X., Lorca, M., Outeiro, L., Bernia, S., Castellnou, M., 2005. Effects of prescribed fire on soil quality in Mediterranean grassland (Prades Mountains, north-east Spain). Int. J. Wildland Fire 14, 379-384.

Úbeda, X., Outeiro, L.R., 2009. Physical and chemical effects of fire in soil. In: Cerdà, A., Robichaud, P.R. (Eds.), Fire Efects on Soils and Restoration Strategies. Science Publishers, Enfield, NH, pp. 105-133.

Úbeda, X., Outeiro, L.R., Sala, M., 2006. Vegetation regrowth after a differential severity forest fire in a Mediterranean environment, Northeast Spain. Land Degrad. Dev. 17, 429-440.

Úbeda, X., Pereira, P., Outeiro, L., Martin, D., 2009. Effects of fire temperature on the physical and chemical characteristics of the ash from two plots of cork oak (Quercus suber). Land Degrad. Dev. 20, 589-608.

Úbeda, X., Sala, M., Imeson, A., 1990. Variaciones en la estabilidad y consistencia de un suelo forestal antes y después de ser sometido a un incendio. In: I Reunión Nacional de Geomorfología, Teruel, pp. 677-685.

Ulery, A., Graham, R.C., Amrhein, C., 1993. Wood-ash composition and soil pH following intense burning. Soil Sci. 156, 358-364.

Ulery, A.L., Graham, R.C., Goforth, B.R., Hubberth, K.R., 2017. Fire effects on cation exchange capacity of California forest and woodland soils. Geoderma 286, $125-130$.

Vance, E.D., Brookes, P.C., Jenkinson, D.S., 1987. An extraction method for measuring soil microbial biomass C. Soil Biol. Biochem. 19, 703-707.

Varela, M.E., Benito, E., Keiser, J.J., 2015. Influence of fire severity on soil physical degradation in two pine forest stands of NW Spain. Catena 133, 342-348.

Vega, J.A., Fonturbel, T., Merino, A., Fernández, C., Ferreiro, C., Jiménez, E., 2013. Testing the ability of visual indicators of burn soil severity to reflect changes in soil chemical and microbial properties in pine forests and shrubland. Plant Soil 396, 73-91.

Vergnoux, A., Di Rocco, R., Domeizel, M., Guiliano, M., Doumenq, P., Theraulaz, F., 2011. Effects of forest fires on water extractable organic matter and humic substances from Mediterranean soils: UV-vis and fluorescence spectroscopy approaches. Geoderma 160, 434-443.

Volkova, L., Meyer, C.P., Murphy, S., Fairman, T., Reisen, F., Weston, C., 2014. Fuel reduction burning mitigates wildfire effects on forest carbon and greenhouse gas emission. Int. J. Wildland Fire 23, 771-780.

Wang, Y., Xu, Z., Zhou, Q., 2014. Impact of fire on soil gross nitrogen transformations in forest ecosystems. J. Soils Sediments 14, 1030-1040.

Wagenberger, J.W., MacDonald, L., Coates, R.N., Robichaud, P.R., Brown, R.E., 2015. Effects of post-fire salvage logging and a skid trail treatment on ground cover, soils, and sediment production in the interior western United States. For. Ecol. Manag. 335, 176-193.

Wagenberger, J.W., Robichaud, P., Brown, R.E., 2016. Rill erosion in burned and salvage logged western montane forests: effects of logging equipment type, traffic level, and slash treatment. J. Hydrol. 541, 889-901.

Wolinska, A., Stepniewska, Z., Pytlak, A., 2015. The effect of environmental factors on total soil DNA content and dehydrogenase activity. Arch. Biol. Sci. 67, 493-501.

Zornoza, R., Mataix-Solera, J., Guerrero, C., Mayoral, A.M., Morales, J., 2007. Soil properties under natural forest in the Alicante Province of Spain. Geoderma $142,334-341$. 